\title{
(2) OPEN ACCESS \\ Beyond cycle lanes and large-scale infrastructure: a scoping review of initiatives that groups and organisations can implement to promote cycling for the Cycle Nation Project
}

\author{
Paul Kelly 지, ${ }^{1}$ Chloë Williamson, ${ }^{1}$ Graham Baker, ${ }^{1}$ Adrian Davis, ${ }^{1,2}$ Sarah Broadfield, ${ }^{3}$ \\ Allison Coles, ${ }^{3}$ Hayley Connell, ${ }^{4}$ Greig Logan, ${ }^{4,5}$ Jill P Pell, ${ }^{4}$ Cindy M Gray, ${ }^{4}$ \\ Jason MR Gill, ${ }^{4,5}$ On behalf of the Cycle Nation Project
}

\begin{abstract}
- Additional material is published online only. To view please visit the journal online (http://dx.doi.org/10.1136/ bjsports-2019-101447).
\end{abstract}

${ }^{1}$ Physical Activity for Health Research Centre, University of Edinburgh, Edinburgh, UK

${ }^{2}$ Transport Research Institute, Edinburgh Napier University, Edinburgh, UK

${ }^{3}$ British Cycling, Manchester, UK ${ }^{4}$ Institute of Health and Wellbeing, University of Glasgow, Glasgow, UK ${ }^{5}$ Institute of Cardiovascular and Medical Sciences, University of Glasgow, Glasgow, UK

\section{Correspondence to} Dr Paul Kelly, Physical Activity for Health Research Centre, University of Edinburgh, Edinburgh EH8 8AQ, UK; p.kelly@ed.ac.uk

Accepted 27 January 2020 Published Online First 8 April 2020
Check for updates

(C) Author(s) (or their employer(s)) 2020. Re-use permitted under CC BY-NC. No commercial re-use. See rights and permissions. Published by BMJ.

\section{To cite: Kelly $P$,}

Williamson C, Baker G,

et al. Br J Sports Med

2020;54:1405-1415.

\section{ABSTRACT}

Background/objectives Cycling has well-established positive relationships with health. Evidence suggests that large-scale infrastructure and built-environment initiatives to promote cycling are likely to be necessary but not sufficient to maximise cycling participation. Smaller-scale initiatives that can be implemented by organisations (eg, employers) and groups (eg, community groups) are therefore also important, but the full range of feasible activities to promote cycling is not known. We aimed to scope the literature and map organisational, social and individual level activities to increase cycling. Methods Design: Scoping review following an established five-stage process.

Eligibility criteria: Studies or publicly available reports describing cycling promotion initiatives deemed feasible for organisations or groups to implement.

Sources of evidence and selection: (i) online databases (Ovid (Medline), Ovid (Embase), SportDISCUS (Ebscohost), ProQuest, Web of Science), (ii) existing systematic reviews, (iii) expert stakeholder consultation. Results We extracted data from 129 studies and reports, from 20 different countries, identifying 145 cycling promotion initiatives. From these initiatives we identified 484 actions within 93 action types within 33 action categories under the nine intervention functions described by Michie et al. Environmental restructuring (micro-level), enablement, education and persuasion were the functions with the most action types, while coercion, modelling and restriction had the fewest action types.

Conclusion This is the first comprehensive map to summarise the broad range of action types feasible for implementation within organisation/group-based cycling promotion initiatives. The map will be a critical tool for communities, employers, practitioners and researchers in designing interventions to increase cycling.

\section{BACKGROUND AND RATIONALE}

Cycling (for transport, commuting or leisure) has well-established positive direct relationships with, and effects on, health. ${ }^{1} \mathrm{~A}$ recent evidence review identified that cycling is associated with reduced risk and lower incidence of multiple physical and mental health conditions. ${ }^{2}$ Systematic review and meta-analysis have shown cycling to be associated with lower risk of premature all-cause mortality. ${ }^{3}$
Indirectly, when cycling replaces motorised transport it can also reduce emissions that harm health and the environment. ${ }^{4}$

With the population and individual benefits of cycling increasingly accepted, it is important to understand what can be done to promote this behaviour. A helpful model for considering the scale, design and implementation of cycling promotion interventions is the ecological model, ${ }^{56}$ which suggests that interventions can be targeted at the: (i) individual level, (ii) social level (including organisational), (iii) physical environment, (iv) the policy level or finally (v) across multiple levels. ${ }^{5}$

There already exists a comprehensive evidence base for cycling (and active travel) interventions and health, characterised by a number of systematic reviews and meta-analyses. These are summarised in table 1 , and show the breadth of evidence for cycling promotion at different levels of the ecological model. The evidence reported in table 1 suggests that there is a considerable body of evidence for the effectiveness of large-scale built environment approaches to promote cycling, with multiple reviews reporting on these approaches. ${ }^{7-13}$ The evidence emphasises the importance of creating safe, designated (or segregated), connected and supportive routes and urban environments. In contrast, there is more of an evidence gap for 'behaviour based' initiatives at the social or individual level, with Stewart et al noting 'little robust evidence' and Savan et al describing a 'paucity of evidence'. ${ }^{14}{ }^{15}$ Porter et al recently noted there is limited evidence for the factors that can affect cycling at the 'institutional level'. ${ }^{16}$

It is clearly helpful and important to know about the evidence for large-scale physical environment interventions. However, many (if not all) of these actions are beyond the reach of communities or organisations such as charities, workplaces or schools who may still have an aim to, or interest in, promoting cycling. Therefore it is also important to understand more about feasible and scalable approaches such organisations could implement. For this purpose, the physical environment could be considered at the macro/micro-levels (see figure 1). A macro-physical environment approach might include new or improved cycle paths and be beyond the scale, cost and planning powers that individual groups and organisations (eg, employers, schools) 
Table 1 An overview of key reviews on potential solutions and facilitators for promoting cycling (studies from non-systematic review of the literature)

\begin{tabular}{|c|c|c|c|}
\hline Study and year & $\begin{array}{l}\text { Level of intervention in } \\
\text { the ecological model }\end{array}$ & Review type & Main findings \\
\hline $\begin{array}{l}\text { Panter et al }{ }^{13} \\
(2019)\end{array}$ & $\begin{array}{l}\text { Policy } \\
\text { Physical } \\
\text { Environment }\end{array}$ & Systematic review & $\begin{array}{l}\text { Reviewed } 13 \text { interventions to promote cycling (and walking) and reported that six had significant } \\
\text { positive effects. Identified three common resources that interventions provide (i) improving } \\
\text { accessibility and connectivity; (ii) improving traffic and personal safety; and (iii) improving the } \\
\text { experience of (walking and) cycling. Despite limited evidence the most effective interventions appear } \\
\text { to target accessibility and safety. }\end{array}$ \\
\hline $\begin{array}{l}\text { Kärmeniemi et al } \\
\text { (2018) }\end{array}$ & $\begin{array}{l}\text { Physical } \\
\text { Environment }\end{array}$ & Systematic review & $\begin{array}{l}\text { Reviewed } 21 \text { prospective cohort studies and } 30 \text { natural experiments. New routes and bike lanes, } \\
\text { traffic free routes, perceived access to destinations, bus-ways with parallel cycling paths and } \\
\text { reductions in perceived danger all predicted increases in cycling. }\end{array}$ \\
\hline $\begin{array}{l}\text { Winters et al }{ }^{10} \\
(2017)\end{array}$ & Policy & Policy review & $\begin{array}{l}\text { Reviewed } 17 \text { review articles. Policies related to active travel may operate at various levels of the } \\
\text { ecological framework, including society, cities, routes or individuals. The provision of convenient, } \\
\text { safe and connected walking and cycling infrastructure is at the core of promoting active travel, but } \\
\text { policies may work best when implemented in comprehensive packages. }\end{array}$ \\
\hline $\begin{array}{l}\text { Savan et al }{ }^{15} \\
(2017)\end{array}$ & $\begin{array}{l}\text { Social } \\
\text { Individual }\end{array}$ & Literature analysis & $\begin{array}{l}\text { Narrative review with number of studies not stated. Five key strategies were reported: (i) strategic } \\
\text { population segmentation; (ii) identification and removal of barriers; (iii) the use of commitment } \\
\text { strategies, including the foot in the door (small initial commitment) and pledge techniques; (iv) } \\
\text { tactics to sustain behaviour change, including visual images, prompts, reminders, social cues and } \\
\text { modelling, social norms, branding, feedback and incentives; and (v) ongoing social support, through } \\
\text { modelling, local hubs and community involvement. }\end{array}$ \\
\hline $\begin{array}{l}\text { Giles-Corti et al }{ }^{11} \\
\text { (2016) }\end{array}$ & $\begin{array}{l}\text { Policy } \\
\text { Physical } \\
\text { Environment }\end{array}$ & Review & $\begin{array}{l}\text { Narrative review with number of studies not stated. Eight 'Urban' and 'Transport planning and } \\
\text { design' policies were reported. Urban design interventions included connective design, residential } \\
\text { density, distance to public transport, land-use diversity and neighbourhood desirability. Planning } \\
\text { interventions included destination accessibility, employment distribution and parking demand } \\
\text { management. }\end{array}$ \\
\hline $\begin{array}{l}\text { Fell and Kivinen }{ }^{17} \\
\text { (2016) }\end{array}$ & $\begin{array}{l}\text { Physical } \\
\text { Environment } \\
\text { Social }\end{array}$ & $\begin{array}{l}\text { Rapid evidence } \\
\text { assessment }\end{array}$ & $\begin{array}{l}\text { Reviewed } 55 \text { studies. Effective interventions included personal travel planning, cycle to work days, } \\
\text { cycle-hire/bike-share schemes, provision of dedicated cycling lanes (and bicycle parking) and some } \\
\text { school-based interventions. The best investment strategy may comprise a strategic, networked } \\
\text { approach and is likely to comprise a mix of measures. }\end{array}$ \\
\hline $\begin{array}{l}\text { Stewart et al }{ }^{14} \\
(2015)\end{array}$ & $\begin{array}{l}\text { Physical } \\
\text { Environment } \\
\text { Social } \\
\text { Individual }\end{array}$ & Systematic review & $\begin{array}{l}\text { Reviewed } 12 \text { studies which aimed to increase commuter cycling and reported: (i) mixed effects for } \\
\text { social and individual level approaches (bike to work (salary sacrifice for purchase) schemes; a self- } \\
\text { help programme; a support programme; cycling training programmes); } 2 \text { ) small, positive effects in } \\
\text { large populations for environmental level approaches (building a bridge; city-wide infrastructure; } \\
\text { whole of city investment approaches). }\end{array}$ \\
\hline $\begin{array}{l}\text { Hunter et al }{ }^{12} \\
(2015)\end{array}$ & $\begin{array}{l}\text { Physical } \\
\text { Environment } \\
\text { Social }\end{array}$ & Systematic review & $\begin{array}{l}\text { Reviewed } 12 \text { studies. An urban greenway trail showed increases in cycling. A promotion campaign } \\
\text { of a newly constructed rail trail showed that intervention group cyclists increased mean cycling time } \\
\text { compared with control area cyclists. }\end{array}$ \\
\hline Mayne et $a l^{8}$ (2015) & $\begin{array}{l}\text { Physical } \\
\text { Environment }\end{array}$ & Systematic review & $\begin{array}{l}\text { Review included six studies with cycling outcomes. Bike lanes and off-street bike paths increased } \\
\text { cycling in three out of four studies. Two studies found increased cycling after implementation of the } \\
\text { London and Montreal bicycle share programmes. }\end{array}$ \\
\hline $\begin{array}{l}\text { Community } \\
\text { Preventive Services } \\
\text { Task Force }^{7} \text { (2015) }\end{array}$ & $\begin{array}{l}\text { Physical } \\
\text { Environment }\end{array}$ & $\begin{array}{l}\text { Systematic review } \\
\text { (non-peer reviewed } \\
\text { US government policy } \\
\text { document) }\end{array}$ & $\begin{array}{l}\text { Reported } 90 \text { studies that provided evidence for the effectiveness of cycling infrastructure including } \\
\text { protected bicycle lanes, trails, traffic calming, intersection design, street lighting and landscaping. }\end{array}$ \\
\hline $\begin{array}{l}\text { Scheepers et } a l^{22} \\
(2014)\end{array}$ & $\begin{array}{l}\text { Physical } \\
\text { Environment } \\
\text { Social } \\
\text { Individual }\end{array}$ & Systematic review & $\begin{array}{l}\text { Of } 14 \text { studies reporting effects on cycling, } 10 \text { reported increases in cycling. Increases in cycling were } \\
\text { demonstrated for an annual short-term campaign, workplace travel plans (eg, storage, subsidised } \\
\text { bicycles, facilities), commuter cycling promotion, financial incentives, car-free city centres, town-wide } \\
\text { initiatives, cycle proficiency classes, individualised marketing, smart bicycles and bicycle sharing } \\
\text { schemes. There were negligible effects for neighbourhood trails, traffic tolls, national cycle networks, } \\
\text { cycle paths. }\end{array}$ \\
\hline Bird et al ${ }^{23}$ (2013) & Individual & Systematic review & $\begin{array}{l}\text { Of } 46 \text { included studies, } 16 \text { reported combined walking and cycling findings (none were cycling } \\
\text { only). While the findings were mixed, they generally supported the inclusion of self-monitoring and } \\
\text { intention formation techniques in future walking and cycling intervention design. }\end{array}$ \\
\hline $\begin{array}{l}\text { National Institute } \\
\text { for Health and Care } \\
\text { Excellence }{ }^{24}(2012)\end{array}$ & $\begin{array}{l}\text { Policy } \\
\text { Physical } \\
\text { Environment } \\
\text { Social } \\
\text { Individual }\end{array}$ & Evidence review & $\begin{array}{l}\text { Reviewed } 47 \text { studies. Evidence-based policy and planning recommendations highlighting the need } \\
\text { to ensure high-level support from the health sector and that all relevant policies and plans consider } \\
\text { (walking and) cycling. Local action recommendations to develop programmes, deliver community } \\
\text { wide-programmes and for personalised travel planning. Recommendations to tackle the wider } \\
\text { influences on (walking or) cycling including measures to reduce road dangers and reallocation of } \\
\text { road space to create a more supportive environment. }\end{array}$ \\
\hline $\begin{array}{l}\text { Fraser et al } \\
\text { (2011) }\end{array}$ & $\begin{array}{l}\text { Physical } \\
\text { Environment }\end{array}$ & Systematic review & $\begin{array}{l}\text { Reviewed } 21 \text { studies. Positive associations were identified between cycling and (i) presence of } \\
\text { dedicated cycle routes or paths, (ii) separation of cycling from other traffic, (iii) high population } \\
\text { density, (iv) short trip distance, (v) proximity of a cycle path or green space; and for children (vi) } \\
\text { projects promoting 'safe routes to school'; negative environmental factors were (vii) perceived and } \\
\text { objective traffic danger, (viii) long trip distance, (ix) steep inclines and (x) distance from cycle paths }\end{array}$ \\
\hline
\end{tabular}


Table 1 Continued

\begin{tabular}{|c|c|c|c|}
\hline Study and year & $\begin{array}{l}\text { Level of intervention in } \\
\text { the ecological model }\end{array}$ & Review type & Main findings \\
\hline Yang et al ${ }^{26}(2010)$ & $\begin{array}{l}\text { Physical } \\
\text { Environment } \\
\text { Social } \\
\text { Individual }\end{array}$ & Systematic review & $\begin{array}{l}\text { Reviewed } 25 \text { studies. An intensive individual-level intervention, high-quality improvements to a cycle } \\
\text { route network, and multifaceted cycle promotion initiatives at town or city level were found to be } \\
\text { associated with increases in cycling. Individualised marketing of 'environmentally friendly' modes of } \\
\text { transport to interested households reported modest but consistent net effects. }\end{array}$ \\
\hline $\begin{array}{l}\text { Bauman et al }{ }^{5} \\
(2008)\end{array}$ & $\begin{array}{l}\text { Policy } \\
\text { Physical } \\
\text { Environment } \\
\text { Social } \\
\text { Individual }\end{array}$ & Literature review & $\begin{array}{l}\text { Policy report with number of studies not stated. Interventions shown to be effective in increasing } \\
\text { cycling included: mass marketing campaigns highlighting the benefits of cycling; bicycle education } \\
\text { programmes to increase skills, confidence and safety; behaviour change initiatives to market } \\
\text { alternatives to car use; cycling events to provide incentives for people to ride in a supportive } \\
\text { environment particularly for novice riders; urban planning; improved bicycle infrastructure; and } \\
\text { funding from all levels of government focused on increasing bicycle friendly design. }\end{array}$ \\
\hline $\begin{array}{l}\text { Ogilvie et a }\left.\right|^{27} \\
\text { (2004) }\end{array}$ & $\begin{array}{l}\text { Physical } \\
\text { Environment } \\
\text { Social } \\
\text { Individual }\end{array}$ & Systematic review & $\begin{array}{l}\text { Reviewed } 22 \text { studies, Results were typically presented for walking and cycling combined with both } \\
\text { controlled and uncontrolled designs. Some evidence that targeted programmes (including provision } \\
\text { of bikes) led to travel behaviour change in motivated groups. There was inconclusive evidence for } \\
\text { other intervention types such as publicity campaigns, engineering measures and financial incentives. }\end{array}$ \\
\hline
\end{tabular}

could implement. A micro-physical environment approach might include installing bike storage, shower facilities, or signage at a school, site or workplace and be feasible for implementation by individual groups and organisations. The reviews in table 1 reveal that the evidence for how to promote cycling at the micro-physical and the social and individual levels is less developed, is less conclusive in terms of findings and is currently an evidence gap.

The evidence gap at micro-physical environment, social and individual levels is important for a number of reasons. As stated earlier, workplaces, schools and community organisations may find implementing programmes involving large infrastructure or policy change infeasible (and unaffordable). These decisions on the introduction of such work are typically in the remit of local or national authorities (eg, government, councils). In addition, Fell and Kivinen (2016) reported a widespread agreement in the literature that the most effective mechanisms for boosting cycling (and walking) comprise integrated and complementary packages of interventions, that is, at all levels of the ecological model. They state that 'Infrastructure is generally regarded as necessary but not sufficient to boost cycling'. ${ }^{17}$ Therefore it is important to identify the feasible approaches that could act at

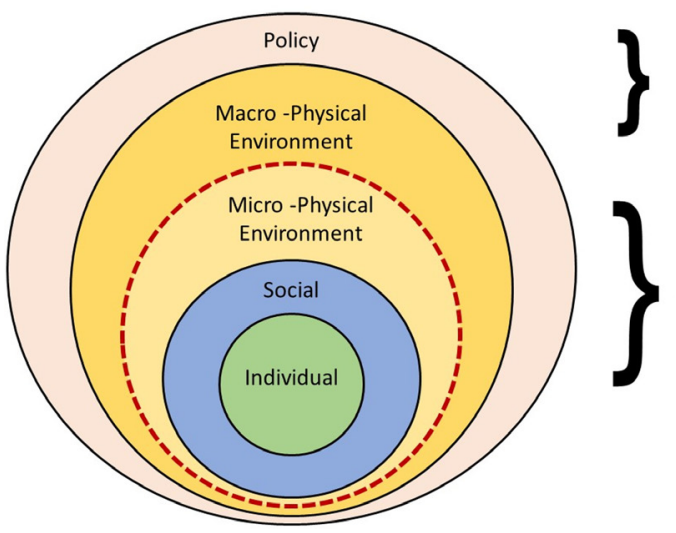

Unlikely to be feasible for groups and organisations

Figure 1 Representation of levels at which cycling promotion can occur highlighting the rationale for investigation at the micro-physical, social and individual levels of the ecological model. Levels within the dotted red line are (more) likely to be feasible for groups and organisations to implement; levels outside of the dotted line are unlikely to be feasible for implementation by groups and organisations. the individual, social and micro-physical environment levels to complement large-scale built environment interventions.

Therefore, despite the evidence presented in table 1 , the full range of feasible and scalable approaches available to promote cycling at the individual, social and micro-physical environmental level to complement infrastructure and policy initiatives remains unclear. There is a need to develop, test and implement cycling interventions that can be delivered effectively, cost-effectively and at scale by groups and organisations to benefit population health. To inform such intervention development, a comprehensive map of all existing cycling promotion approaches is required. This includes those that have not yet undergone impact/outcome evaluation, or those with equivocal evaluation findings to date. This avoids what has been called the 'Dangerous Olive of Evidence' which refers to the phenomenon by which new interventions focus on what has already been extensively researched in controlled designs. ${ }^{18}$ This would limit any future interventions to those interventions that are already known or are easy to evaluate, potentially acting as a barrier to novel and effective health promotion.

\section{Objectives}

Based on the earlier arguments, we aimed to scope the literature and present what is known in terms of all possible ways to promote cycling at the individual, social and micro-physical environment levels that is, those that would be feasible for groups and organisations to implement. We mapped these actions according to broader identified action categories, and these categories were mapped to the nine intervention functions described by Michie et al. ${ }^{19}$ This approach provides a broad menu of techniques and strategies, which could be used to inform the design of future interventions to promote cycling at levels below the macro-built environment.

Table 2 Search terms for cycling promotion interventions

\begin{tabular}{ll}
\hline Cycling terms & Intervention terms \\
\hline Bicycle, bike, biking, cycle hire, cycling, & Intervention, campaign, encourage, \\
active commute, active transport, active & habit, impact, increase, pattern, policy, \\
travel, green commute, & programme, project, promotion, scheme, \\
green transport, ecological commute, & shift, start, behaviour change, incentive, \\
ecological transport, ecological travel, & initiative, provision \\
non-motorised travel, non-motorised & \\
travel, non-auto travel & \\
\hline
\end{tabular}




\begin{tabular}{|c|c|c|c|c|c|}
\hline Study & Initiative & Function & Action Categories & Action Type & Description \\
\hline \multirow[t]{4}{*}{ Smith et al., (2017) } & $\begin{array}{l}\text { The "Cycle to Work" } \\
\text { project }\end{array}$ & C. Incentivisation & C2. Financial & $\begin{array}{l}\text { C2.4 Cash or vouchers for } \\
\text { modal shift to cycling or } \\
\text { increasing cycling }\end{array}$ & $\begin{array}{l}\text { Financial incentives in the form of } \\
\text { gift vouchers if participants attended } \\
\text { a certain number of cycling sessions }\end{array}$ \\
\hline & & A. Education & $\begin{array}{l}\text { A1. Increasing knowledge or } \\
\text { understanding of benefits of } \\
\text { cycling }\end{array}$ & $\begin{array}{l}\text { A1.3 Information on } \\
\text { health benefits of PA and } \\
\text { cycling }\end{array}$ & $\begin{array}{l}\text { Leaflet with statistics about reduced } \\
\text { risk of diabetes in people who cycle }\end{array}$ \\
\hline & & & $\begin{array}{l}\text { A3. Route planning/personal and } \\
\text { individualised travel planning }\end{array}$ & A3.2 Travel maps & $\begin{array}{l}\text { Provision of maps showing local } \\
\text { cycle route and travel options }\end{array}$ \\
\hline & & $\begin{array}{l}\text { G. Environmental } \\
\text { restructuring (physical } \\
\text { context) }\end{array}$ & G1 Bicycle storage & $\begin{array}{l}\text { G1.1 Provide bicycle } \\
\text { storage facilities }\end{array}$ & $\begin{array}{l}\text { Install bicycle racks at entrance to } \\
\text { workplace }\end{array}$ \\
\hline
\end{tabular}

PA, physical activity.

\section{METHODS}

\section{Design}

Scoping review. We were guided by the established five-stage scoping review process proposed by Arksey and O'Malley. ${ }^{20}$

\section{Stage 1: identifying the research question}

The research question was refined and agreed by the study team, with a view to generating a map of cycling promotion actions that would inform the design, testing and/or implementation of cycling promotion initiatives. Our research question was: what are the different approaches that have been used at the individual, social or micro-physical environment level to try and promote cycling, and how do they map to the nine intervention functions described in Michie et al's behaviour change wheel? ${ }^{19}$

\section{Stage 2: identifying relevant studies}

\section{Data sources}

- Online databases including: (Ovid (Medline), Ovid (Embase), SportDISCUS (Ebscohost), ProQuest, Web of Science).

- Searching reference list of existing reviews.

- Expert stakeholder consultation. This involved creating a contact list of international experts. Two of the authors (AC and $\mathrm{SB}$ ) worked for the national governing body for cycling in Great Britain and were able to provide a comprehensive list of expert contacts beyond academic networks.

\section{Search terms}

Databases were searched (up to July 2018) for titles and abstracts that combined at least one 'cycling' term with at least one 'intervention' term (see table 2) within five words of each other. Appropriate truncation symbols and wild cards were used to account for variations of the search terms and maximise searches.

\section{Terminology}

Within the cycling promotion literature, and highlighted by the reviews in table 1 , there is considerable inconsistency in the terminology used to describe and categorise activities to promote cycling. This is at both the broad level where terms such as initiative, tool and programme have been used, and when describing specific intervention components using terms such as actions and techniques. Similarly, attempts to categorise the main aim or type of intervention components have been inconsistent. While some studies have linked components to spatial or social categories, for example Winters et al, ${ }^{10}$ this is not always the case. Therefore, to give a structure and framework for this review we operationalised the following terminology and hierarchy:
- Study: a report or article that describes a cycling promotion 'initiative'.

- Initiative: a project, intervention or policy that aims to increase cycling.

- Function: we utilised the nine over-arching intervention functions proposed by Michie et al to categorise the broadest, main approach of a cycling initiative. The nine functions were developed from a systematic review of 19 existing frameworks of behaviour change interventions and are as follows: education, persuasion, incentivisation, coercion, training, restriction, environmental restructuring, modelling and enablement. ${ }^{19}$ These functions therefore represent what is currently the most comprehensive method to reliably classify activities that are aimed at changing behaviour using consistent and precise definitions.

- Action category: a collection of similar action types organised by function.

- Action type: a defined technique, initiative component, strategy, or approach found within 'initiatives' to increase cycling.

Table 3 provides a hypothetical example using these key terms. This shows that a given initiative can contain multiple actions which can be mapped to action categories organised under top level functions.

\section{Stage 3: study selection}

Studies were included if they met all of the following inclusion criteria:

- Research articles or reports published in English available as (any of):

- Published in peer-reviewed academic journals.

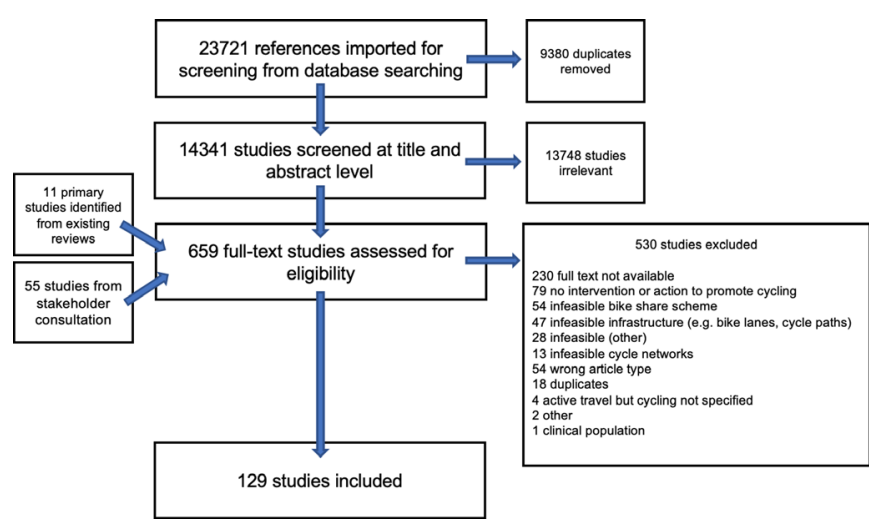

Figure 2 Flow diagram of study selection process. 
Table 4 Action categories within each intervention function

\begin{tabular}{|c|c|c|}
\hline $\begin{array}{l}\text { Function definition from Michie } \\
\text { et al }\end{array}$ & $\begin{array}{l}\text { Action categories within } \\
\text { function }\end{array}$ & $\begin{array}{l}\text { Number of times actions } \\
\text { identified within actions } \\
\text { categories }\end{array}$ \\
\hline \multirow[t]{6}{*}{$\begin{array}{l}\text { A. Education } \\
\text { Increasing knowledge or } \\
\text { understanding }\end{array}$} & $\begin{array}{l}\text { A1. Increasing knowledge } \\
\text { or understanding of benefits } \\
\text { of cycling }\end{array}$ & 27 \\
\hline & $\begin{array}{l}\text { A2. Increasing knowledge } \\
\text { or understanding of cycling } \\
\text { safety }\end{array}$ & 23 \\
\hline & $\begin{array}{l}\text { A3. Route planning/personal } \\
\text { and individualised travel } \\
\text { planning }\end{array}$ & 44 \\
\hline & $\begin{array}{l}\text { A4. Practical or instrumental } \\
\text { information }\end{array}$ & 4 \\
\hline & $\begin{array}{l}\text { A5. Signposting to cycling- } \\
\text { related contacts }\end{array}$ & 1 \\
\hline & Sub-total & 99 \\
\hline \multirow{6}{*}{$\begin{array}{l}\text { B. Persuasion } \\
\text { Using communication to induce } \\
\text { positive or negative feelings or } \\
\text { stimulate action }\end{array}$} & B1. One-to-one counselling & 8 \\
\hline & B2. Group counselling & 2 \\
\hline & $\begin{array}{l}\text { B3. Tailored intervention } \\
\text { actions }\end{array}$ & 13 \\
\hline & $\begin{array}{l}\text { B4. Travel diaries with } \\
\text { feedback }\end{array}$ & 5 \\
\hline & B5. Mass media campaigns & 21 \\
\hline & Sub-total & 49 \\
\hline \multirow{4}{*}{$\begin{array}{l}\text { C. Incentivisation } \\
\text { Creating expectation of reward }\end{array}$} & C1. Material & 8 \\
\hline & C2. Financial & 22 \\
\hline & $\begin{array}{l}\text { C3. Points, prizes, } \\
\text { gamification and challenges }\end{array}$ & 38 \\
\hline & Sub-total & 68 \\
\hline \multirow{2}{*}{$\begin{array}{l}\text { D. Coercion } \\
\text { Creating expectation of punishment } \\
\text { or cost }\end{array}$} & $\begin{array}{l}\text { D1. Increased paid vehicle } \\
\text { parking }\end{array}$ & 3 \\
\hline & Sub-total & 3 \\
\hline \multirow[t]{3}{*}{$\begin{array}{l}\text { E. Training } \\
\text { Imparting skills }\end{array}$} & $\begin{array}{l}\text { E1. Practical cycling training } \\
\text { courses and sessions }\end{array}$ & 52 \\
\hline & $\begin{array}{l}\text { E2. Cycle awareness training } \\
\text { for vehicle drivers }\end{array}$ & 1 \\
\hline & Sub-total & 53 \\
\hline \multirow{2}{*}{$\begin{array}{l}\text { F. Restriction } \\
\text { Using rules to reduce the } \\
\text { opportunity to engage in target } \\
\text { behaviour (or to increase the } \\
\text { target behaviour by reducing the } \\
\text { opportunity to engage in competing } \\
\text { behaviours) }\end{array}$} & $\begin{array}{l}\text { F1. Reducing free vehicle } \\
\text { parking }\end{array}$ & 2 \\
\hline & Sub-total & 2 \\
\hline \multirow{14}{*}{$\begin{array}{l}\text { G. Environmental restructuring } \\
\text { Changing the physical or social } \\
\text { context }\end{array}$} & Physical context & \\
\hline & G1. Bike storage & 31 \\
\hline & $\begin{array}{l}\text { G2. Bike maintenance } \\
\text { facilities }\end{array}$ & 6 \\
\hline & G3. Facilities for cyclists & 13 \\
\hline & $\begin{array}{l}\text { G4. Bike wheel channels } \\
\text { on stairs }\end{array}$ & 5 \\
\hline & G5. Safety features & 8 \\
\hline & G6. Route signage & 3 \\
\hline & Sub-total & 66 \\
\hline & Social context & \\
\hline & $\begin{array}{l}\text { G7. Cycling-related } \\
\text { personnel }\end{array}$ & 8 \\
\hline & $\begin{array}{l}\text { G8. Large events and mass } \\
\text { participation }\end{array}$ & 32 \\
\hline & G9. Group cycling & 27 \\
\hline & $\begin{array}{l}\text { G10. Workplace or } \\
\text { organisational policies }\end{array}$ & 16 \\
\hline & Sub-total & 83 \\
\hline \multirow{2}{*}{$\begin{array}{l}\text { H. Modelling } \\
\text { Providing an example for people to } \\
\text { aspire to or imitate }\end{array}$} & H1. 'Buddying' systems & 3 \\
\hline & Sub-total & 3 \\
\hline
\end{tabular}

Continued

\begin{tabular}{|c|c|c|}
\hline $\begin{array}{l}\text { Function definition from Michie } \\
\text { et al }\end{array}$ & $\begin{array}{l}\text { Action categories within } \\
\text { function }\end{array}$ & $\begin{array}{l}\text { Number of times actions } \\
\text { identified within actions } \\
\text { categories }\end{array}$ \\
\hline \multirow{7}{*}{$\begin{array}{l}\text { I. Enablement } \\
\text { Increasing means/reducing barriers } \\
\text { to increase capability or opportunity }\end{array}$} & $\begin{array}{l}\text { I1. Provision of bike } \\
\text { accessories }\end{array}$ & 12 \\
\hline & 12. Provision of eBikes & 4 \\
\hline & 13. Provision of bikes & 26 \\
\hline & $\begin{array}{l}\text { 14. Small-scale bike share } \\
\text { schemes }\end{array}$ & 5 \\
\hline & $\begin{array}{l}\text { 15. Provision of bike } \\
\text { maintenance }\end{array}$ & 11 \\
\hline & Sub-total & 58 \\
\hline & Overall total & 484 \\
\hline
\end{tabular}

- Dissertations, or PhD/Master's theses.

- Publicly available reports or evaluation reports.

- Described an initiative that aimed to promote cycling (this could be primary, secondary or tertiary aim; study had to explicitly state this aim, or imply it by measuring cyclingrelated outcomes).

Both quantitative and qualitative studies were eligible and studies from any geographical location or setting that included any age group or sex were included if they met the inclusion criteria. Studies that gave no description of the cycling initiative, or were editorials, opinion pieces or reports of hypothetical initiatives were excluded.

\section{Stage 4: Charting the data}

For each initiative, key information from the relevant included studies was extracted into a standard data form (using Microsoft Excel). Information extracted included author, year, location, design, sample size and characteristics, setting, scale, initiative characteristics (including function, action category and action), outcome measures and findings, and delivery costs and economic evaluation (where available).

\section{Stage 5: Collating, summarising and reporting the results}

The analytic framework for collating the data was based on describing presence and categorisation of functions, action categories and actions within the identified cycling initiatives.

\section{RESULTS}

After removing duplicates, a total of 14407 studies were identified for screening from a combination of searching databases $(n=14341)$, reference lists of existing systematic reviews $(\mathrm{n}=11)$ and stakeholder consultation $(\mathrm{n}=55)$ (see figure 2). Ultimately, 129 studies were included in the final analysis. See online supplementary file 1 for the list of included studies with basic study characteristics. Detailed data extraction by study is presented in online supplementary file 2 . These resources can be used to identify the original empirical report for each action type and find out more detail about specified action types in each initiative.

\section{Descriptive characteristics}

In total, these 129 studies described 145 initiatives that took place across 20 different countries. 101 studies (78\%) were from peer-reviewed journals and 28 (22\%) were from 'grey literature' sources. Twelve studies (9\%) came from stakeholder consultation and all were classified as grey literature. The majority of initiatives took place in the UK $(n=45 ; 31 \%)$, USA $(\mathrm{n}=38 ; 26 \%)$ and Australia $(\mathrm{n}=18 ; 12 \%)$ with the remaining 
Table 5 Descriptions and frequencies of cycling action types under the education function

\begin{tabular}{|c|c|c|c|c|c|}
\hline \multicolumn{6}{|c|}{ A. Education } \\
\hline Code & Action category & Code & Action type & No of times action type used & $\begin{array}{l}\text { Percentage of } \\
\text { overall actions }\end{array}$ \\
\hline \multirow[t]{4}{*}{ A1 } & \multicolumn{3}{|c|}{ Increasing knowledge or understanding of benefits of cycling } & 27 & 5.5 \\
\hline & & A1.1 & Information on general (combined or unspecified) benefits of PA and cycling & 15 & 3.1 \\
\hline & & A1.2 & Information on environmental impact and carbon offset of cycling & 5 & 1 \\
\hline & & A1.3 & Information on health benefits of PA and cycling & 4 & 0.8 \\
\hline \multirow[t]{4}{*}{ A2 } & \multicolumn{3}{|c|}{ Increasing knowledge or understanding of cycling safety } & 23 & 4.7 \\
\hline & & A2.1 & Information on safety of cycling & 5 & 1 \\
\hline & & $\mathrm{A} 2.2$ & Information on how to cycle safely & 16 & 3.3 \\
\hline & & A2.3 & Acting out travel scenes & 2 & 0.4 \\
\hline \multirow[t]{2}{*}{ A3 } & \multicolumn{3}{|c|}{ Route planning/personal and individualised travel planning } & 44 & 8.6 \\
\hline & & A3.5 & Information website or application & 3 & 0.6 \\
\hline \multirow[t]{4}{*}{ A4 } & \multicolumn{3}{|c|}{ Practical or instrumental information } & 4 & 0.8 \\
\hline & & A4.1 & Local showering options & 1 & 0.2 \\
\hline & & A4.2 & Local storage options & 2 & 0.4 \\
\hline & & A4.3 & $\begin{array}{l}\text { General practical information (eg, 'everything you need to know about cycling } \\
\text { to work' booklet) }\end{array}$ & 1 & 0.2 \\
\hline \multirow[t]{3}{*}{ A5 } & \multicolumn{3}{|c|}{ Signposting to cycling-related contacts } & 1 & 0.2 \\
\hline & & A5.1 & Provide useful cycling-related contact telephone numbers & 1 & 0.2 \\
\hline & & & Total in 'Education' & 99 & 20.5 \\
\hline
\end{tabular}

PA, physical activity.

44 initiatives (30\%) coming from 17 countries (mainly European countries but also Brazil, Canada, Columbia and New Zealand). The initiatives were implemented across a range of settings including school $(\mathrm{n}=38 ; 26 \%)$, community $(\mathrm{n}=27$; $18 \%)$ and workplace $(n=22 ; 15 \%)$. Initiatives were frequently implemented in multiple settings $(n=32 ; 22 \%)$, with online

Table 6 Descriptions and frequencies of cycling actions under the persuasion function

B. Persuasion

\begin{tabular}{|c|c|c|c|c|c|}
\hline Code & Action category & Code & Action type & No of times action type used & $\begin{array}{l}\text { Percentage of overall } \\
\text { actions }\end{array}$ \\
\hline \multirow[t]{3}{*}{ B1 } & One-to-one counselling & & & 8 & 2 \\
\hline & & B1.1 & $\begin{array}{l}\text { Barrier identification and } \\
\text { solutions }\end{array}$ & 6 & 1.4 \\
\hline & & B1.2 & $\begin{array}{l}\text { Offering motivation to alter } \\
\text { travel behaviour }\end{array}$ & 2 & 0.4 \\
\hline \multirow[t]{2}{*}{ B2 } & Group counselling & & & 2 & 0.4 \\
\hline & & B2.1 & $\begin{array}{l}\text { Group counselling to increase } \\
\text { cycling }\end{array}$ & 2 & 0.4 \\
\hline \multirow[t]{4}{*}{ B3 } & Tailored intervention actions & & & 13 & 2.7 \\
\hline & & B3.1 & $\begin{array}{l}\text { Tailored phone calls to nudge } \\
\text { behaviour change }\end{array}$ & 1 & 0.2 \\
\hline & & B3.2 & Tailored letters & 4 & 0.8 \\
\hline & & B3.3 & Tailored messaging & 8 & 1.7 \\
\hline \multirow[t]{2}{*}{ B4 } & Travel diaries with feedback & & & 5 & 1 \\
\hline & & B4.1 & $\begin{array}{l}\text { Individualised travel diaries } \\
\text { with feedback }\end{array}$ & 5 & 1 \\
\hline \multirow[t]{5}{*}{ B5 } & Mass media campaigns & & & 21 & 4.4 \\
\hline & & B5.1 & $\begin{array}{l}\text { Media promoting specific } \\
\text { project }\end{array}$ & 11 & 2.3 \\
\hline & & B5.2 & $\begin{array}{l}\text { Media promoting cycling in } \\
\text { general }\end{array}$ & 9 & 1.9 \\
\hline & & B5.3 & Media discouraging car use & 1 & 0.2 \\
\hline & & & Total in 'Persuasion' & 49 & 10.5 \\
\hline
\end{tabular}


Table 7 Descriptions and frequencies of cycling actions under the incentivisation function

\begin{tabular}{|c|c|c|c|c|c|}
\hline \multicolumn{6}{|c|}{ C. Incentivisation } \\
\hline Code & Action category & Code & Action type & $\begin{array}{l}\text { No of times action } \\
\text { type used }\end{array}$ & $\begin{array}{l}\text { Percentage of } \\
\text { overall actions }\end{array}$ \\
\hline \multirow[t]{6}{*}{ C1 } & Material & & & 8 & 1.6 \\
\hline & & $\mathrm{C} 1.1$ & Bikes for attending sessions & 1 & 0.2 \\
\hline & & $\mathrm{C} 1.2$ & Branded goods (pens, pencils, hats) for cycling & 3 & 0.6 \\
\hline & & $\mathrm{C} 1.3$ & Food and prizes for cycling on designated days & 1 & 0.2 \\
\hline & & C1.4 & Time off work for cycling & 2 & 0.4 \\
\hline & & $\mathrm{C} 1.5$ & Vehicle scrappage including a bike rebate & 1 & 0.2 \\
\hline \multirow[t]{8}{*}{ C2 } & Financial & & & 22 & 4.5 \\
\hline & & $\mathrm{C} 2.1$ & Subsidy, salary sacrifice, tax free loan for buying bicycle & 4 & 0.8 \\
\hline & & $\mathrm{C} 2.2$ & Subsidy, salary sacrifice, tax free loan for buying equipment & 1 & 0.2 \\
\hline & & $\mathrm{C} 2.3$ & Retail and repair cost discounts for cycling & 3 & 0.6 \\
\hline & & $\mathrm{C} 2.4$ & Cash or vouchers for modal shift to cycling or increasing cycling & 9 & 1.9 \\
\hline & & $\mathrm{C} 2.5$ & Bike vouchers & 2 & 0.4 \\
\hline & & $\mathrm{C} 2.6$ & Free bike service for taking part & 1 & 0.2 \\
\hline & & $\mathrm{C} 2.7$ & Cycling-related gifts & 2 & 0.4 \\
\hline \multirow[t]{9}{*}{ C3 } & Points, prizes, ga & ion an & & 38 & 7.8 \\
\hline & & C3.1 & Goal setting, targets and challenges & 12 & 2.5 \\
\hline & & C3.2 & Reward schemes for cycling & 3 & 0.6 \\
\hline & & C3.3 & Awards, certificates or acknowledgements & 1 & 0.2 \\
\hline & & C3.4 & Leaderboards and prizes & 10 & 2.1 \\
\hline & & C3.5 & Within workplace/school team challenge & 6 & 1.2 \\
\hline & & C3.6 & Between workplace/school team challenge & 4 & 0.8 \\
\hline & & C3.7 & Active games (such as Beat the Street) & 2 & 0.4 \\
\hline & & & Total in 'Incentivisation' & 68 & 14.5 \\
\hline
\end{tabular}

Table 8 Descriptions and frequencies of cycling actions under the coercion function D. Coercion

\begin{tabular}{|c|c|c|c|c|c|}
\hline Code & Action category & Code & Action type & No of times action type used & $\begin{array}{l}\text { Percentage of } \\
\text { overall actions }\end{array}$ \\
\hline \multirow[t]{4}{*}{ D1 } & Increased paid v & cle parking & & 3 & 0.6 \\
\hline & & D1.1 & Expand paid car park & 1 & 0.2 \\
\hline & & D1.3 & Parking infringements enforced by parking officers & 1 & 0.2 \\
\hline & & & Total in 'Coercion' & 3 & 0.1 \\
\hline
\end{tabular}

Table 9 Descriptions and frequencies of cycling actions under the training function

\begin{tabular}{|c|c|c|c|c|c|}
\hline \multicolumn{6}{|c|}{ E. Training } \\
\hline Code & Action category & Code & Action type & No of times action type used & Percentage of overall actions \\
\hline \multirow[t]{5}{*}{ E1 } & \multicolumn{3}{|c|}{ Practical cycling training courses and sessions } & 52 & 8.6 \\
\hline & & E1.1 & Skills and proficiency training and courses & 33 & 6.8 \\
\hline & & E1.2 & Safety training and courses & 10 & 2.1 \\
\hline & & E1.3 & $\begin{array}{l}\text { General (both skills and safety or unspecified) } \\
\text { cycle training and courses }\end{array}$ & 8 & 1.7 \\
\hline & & E1.4 & Independent skills practice & 1 & 0.2 \\
\hline \multirow[t]{3}{*}{ E2 } & Cycle awareness & ing for & & 1 & 0.2 \\
\hline & & E2.1 & Cycle awareness training for drivers & 1 & 0.2 \\
\hline & & & Total in 'Training' & 53 & 11 \\
\hline
\end{tabular}

$(\mathrm{n}=3 ; 2 \%)$, university $(\mathrm{n}=4 ; 3 \%)$, home $(\mathrm{n}=13 ; 9 \%)$ and other $(n=6 ; 4 \%)$ making up the remainder. In terms of target age, $n=65(48 \%)$ initiatives focused on adults, $n=38(26 \%)$ on children, $n=1(<1 \%)$ on older adults and $n=42(29 \%)$ on multiple age groups.
Outcome evaluation

Of the 145 initiatives, 119 (82\%) included outcome evaluation: $74(51 \%)$ measured only cycling as an outcome, 15 (10\%) measured only antecedents of cycling, for example, intent to cycle 


\begin{tabular}{|c|c|c|c|c|c|}
\hline \multicolumn{6}{|c|}{ F. Restriction } \\
\hline Code & Action category & Code & Action type & No of times action type used & Percentage of overall actions \\
\hline \multirow[t]{4}{*}{ F1 } & Reducing free ve & parking & & 2 & 0.4 \\
\hline & & $\mathrm{F} 1.1$ & Reduce number of vehicle parking spaces & 1 & 0.2 \\
\hline & & $\mathrm{F} 1.2$ & Removal of car 'drop off' zone & 1 & 0.2 \\
\hline & & & Total in 'Restriction' & 2 & 0.4 \\
\hline
\end{tabular}

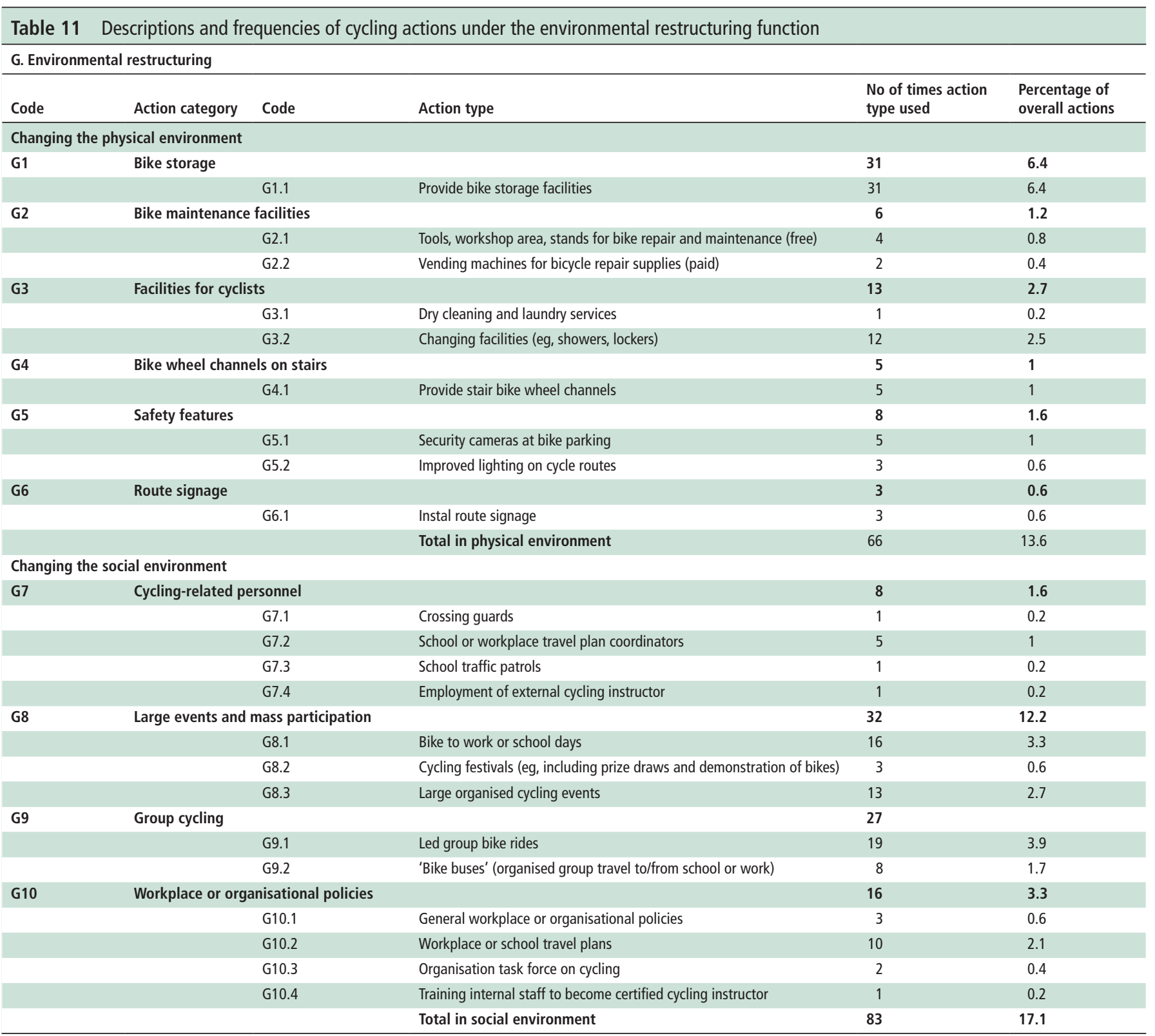

or attitude towards cycling, 20 (14\%) measured both cycling and one or more antecedent and $13(9 \%)$ measured general active travel or physical activity where cycling-related outcomes were not able to be isolated. 45 (31\%) provided cost data, and $9(6 \%)$ conducted an economic evaluation. Further details are reported in the online supplementary file 1.

\section{Functions, action categories and action types}

From the 145 initiatives, across the nine intervention functions, we identified 33 distinct action categories and 93 independent action types (see table 4). In total, there were 484 instances of one of the 93 action types. The number of action types to promote cycling in each initiative ranged from one to a maximum of 10 , with the mean number of actions types being 3.3 per initiative (median=3).

Environmental restructuring had 10 independent action categories (the highest of the nine intervention functions). Education, enablement and persuasion were next with five action categories each. Conversely, modelling, restriction and coercion only had one action category each. 
Table 12 Descriptions and frequencies of cycling actions under the modelling function

\begin{tabular}{|c|c|c|c|c|c|}
\hline \multicolumn{6}{|c|}{ H. Modelling } \\
\hline Code & Action category & Code & Action type & $\begin{array}{l}\text { No of times action type } \\
\text { used }\end{array}$ & $\begin{array}{l}\text { Percentage of } \\
\text { overall actions }\end{array}$ \\
\hline \multirow[t]{4}{*}{ H1 } & 'Buddying' systems & & & 3 & 0.6 \\
\hline & & $\mathrm{H} 1.1$ & $\begin{array}{l}\text { Bike mentoring-pairing less experienced } \\
\text { cyclist with more experienced cyclist }\end{array}$ & 2 & 0.4 \\
\hline & & $\mathrm{H} 1.2$ & Online eBuddy system & 1 & 0.2 \\
\hline & & & Total in 'Modelling' & 3 & 0.6 \\
\hline
\end{tabular}

The action categories are further described in terms of their component actions types in tables $5-13$. These tables report each of the 93 action types by action category and intervention function. We also report the number of times each action type was identified in the 145 included initiatives.

The full comprehensive map of functions, action categories and actions to promote cycling is shown in figure 3. This depicts visually the functions that have more variation and a greater number of independent action options to promote cycling (eg, education and environmental restructuring) compared with those with limited actions to choose from (eg, modelling, restriction or coercion).

\section{DISCUSSION}

This is the first study to comprehensively map, and categorise at various levels, the range of cycling promotion actions that could be implemented by groups and organisations to promote cycling. We found that there is a broad spectrum of action types used to promote cycling and these can be organised by action categories and further mapped to the nine intervention functions proposed by Michie et al. ${ }^{19}$ Environmental restructuring, education, enablement and persuasion were the functions with the most different action categories and subsequent action types. Modelling, restriction and coercion had the fewest action categories and action types. These actions types have demonstrated feasibility as our inclusion criteria was documented reporting of their use. However, as most identified initiatives included multiple actions, the effectiveness of each specific action and relative effectiveness to each other remains unclear, and an area for future investigation.

This paper is the first to map cycling promotion actions that could be considered feasible for individual groups and organisations (eg, employers, schools) to implement. Importantly, as it is not an 'effectiveness review' it will not be biased to those initiatives (and actions) that are easier or cheaper to test and evaluate, or those that have historically been selected for initiatives. As a result (to the best of our knowledge), it includes a far more detailed and comprehensive map of action types and action categories than has been published before. However, as a consequence, we are unable to report on effectiveness of the specific actions. This is in contrast to reviews such as Fell and Kivinen ${ }^{17}$ though these generally report effectiveness of initiatives, rather than their component actions.

There are a number of strengths of our approach. We have provided a comprehensive map to inform design, implementation and evaluation of cycling promotion initiatives. This will be a critical tool for individual groups and organisations planning to promote cycling or test approaches. Our map could be

Table 13 Descriptions and frequencies of cycling actions under the enablement function

\begin{tabular}{|c|c|c|c|c|c|}
\hline \multicolumn{6}{|c|}{ I. Enablement } \\
\hline Code & Action category & Code & Action & $\begin{array}{l}\text { No of times action type } \\
\text { used }\end{array}$ & Percentage of overall actions \\
\hline \multirow[t]{2}{*}{11} & \multicolumn{3}{|c|}{ Provision of bike accessories } & 12 & 2.5 \\
\hline & & 11.2 & Cycling-related merchandise & 1 & 0.2 \\
\hline 12 & Provision of eBik & & & 4 & 0.8 \\
\hline \multirow[t]{4}{*}{13} & Provision of bike & & & 26 & 5.4 \\
\hline & & 13.1 & Provision of bike to keep & 2 & 0.4 \\
\hline & & 13.2 & $\begin{array}{l}\text { Short-term hire or lease of bike/bike taster } \\
\text { session }\end{array}$ & 9 & 1.9 \\
\hline & & 13.3 & Provision of bike to use during intervention & 5 & 1 \\
\hline \multirow{2}{*}{14} & & 14.1 & Workplace 'errand' bikes & 3 & 0.6 \\
\hline & & 14.2 & Provision of shared bikes & 2 & 0.4 \\
\hline \multirow[t]{4}{*}{15} & Provision of bike & nance & & 11 & 2.3 \\
\hline & & 15.1 & General bike maintenance & 9 & 1.9 \\
\hline & & 15.2 & Bike repairs & 2 & 0.4 \\
\hline & & & Total in 'Enablement' & 58 & 12.2 \\
\hline
\end{tabular}




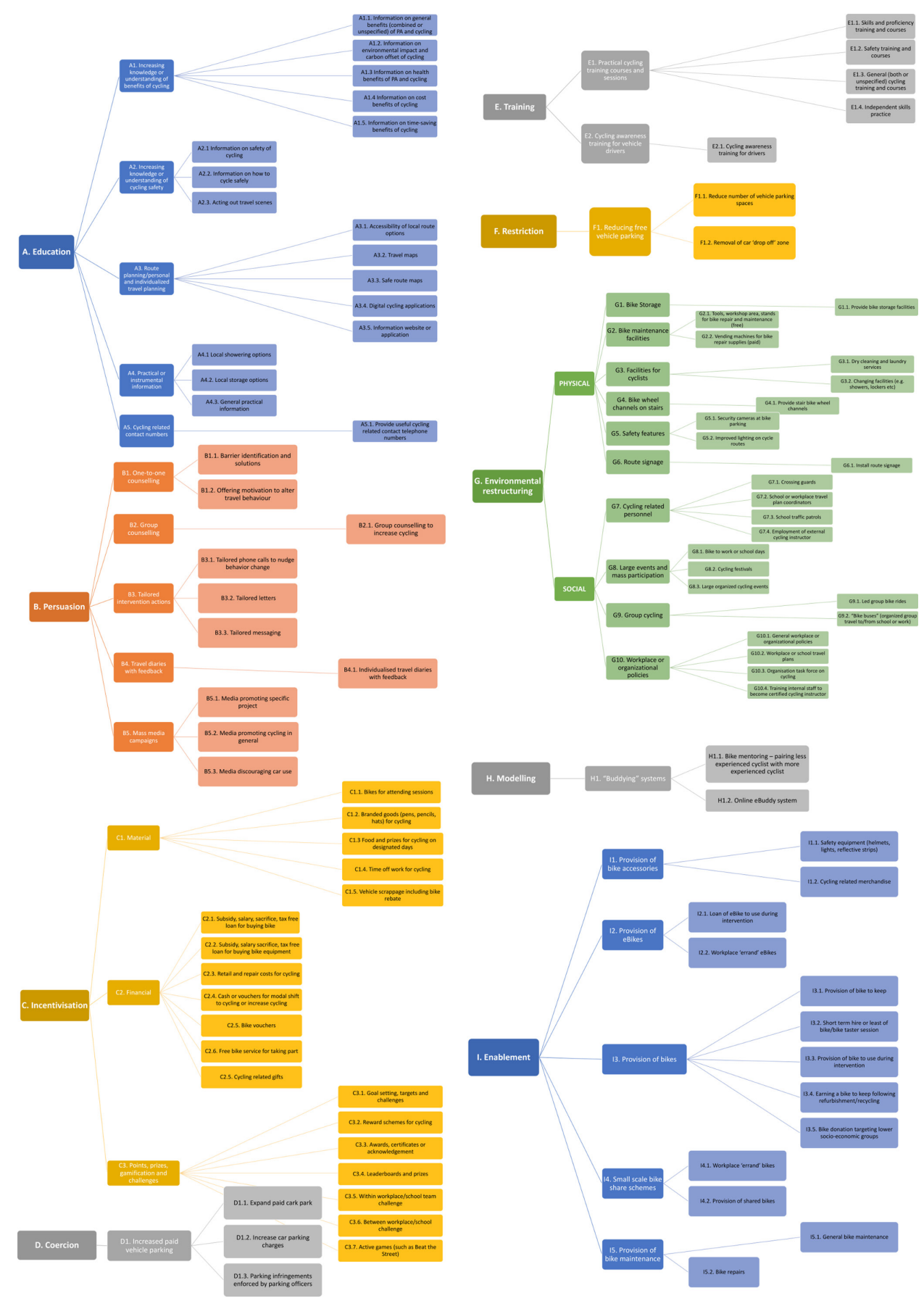

Figure 3 Map of cycling promotion functions, action categories and action types.

used by a broad range of stakeholders from workplaces (small and large, national and local), schools, community groups and local charities to develop feasible cycling interventions aimed at addressing the specific barriers to cycling participation in their local context. It could inform future intervention testing, and the application of novel (and novel combinations of) approaches to context and setting specific barriers. The map can also be used to find out more about specified actions by using online supplementary file 1 to identify the original empirical report of this action.

A worked example showing the application of our review findings is shown in online supplementary file 3. Once locally relevant barriers to cycling have been identified, appropriate intervention functions can be selected from the nine possible options. Michie et al state that a theoretical understanding of the behaviour in question (here cycling) can be used to determine which of the intervention functions are likely to be effective. ${ }^{19}$ Our action map can then be used to identify the range of options available under this intervention function to address this barrier. It is up to the local cycling promotion to select the most appropriate and feasible actions based on factors such as local context, existing support, resource availability and recipient preferences.

It is a strength that we have mapped actions using the intervention functions component of the behaviour change wheel. ${ }^{19}$ The behaviour change wheel is an evidence-based framework that has been used extensively, and by organising the actions in this way stakeholders will be able to identify potential strategies to overcome known barriers in their own local contexts. We 
acknowledge that, as per the authors' definition of an intervention function, ${ }^{19}$ it may be possible for a specific action type to be placed under more than one function. However, it was possible in all instances to classify actions to one main function by linking the authors' description to the most appropriate intervention function definition.

All the interventions included in this review have been demonstrated to be feasible to implement in at least one context, but we have not reported on effectiveness in our map. We believe that this is a strength, as to have done so would have introduced bias as previously discussed and limited the breadth of the identified actions. In addition, we were scoping at the level of specific action types and most initiatives incorporated multiple actions (mean of 3.3 actions), while effectiveness (if reported) would be at the study/initiative level. As studies rarely reported effectiveness of an individual action, attempting to attribute effect to a single action in an initiative is problematic. As recently reported in an examination of methods to determine the effectiveness of behaviour change techniques, this process is inherently difficult to perform due to limitations of the possible methods such as meta-regression or meta-classification and regression trees (CART). ${ }^{21}$ Thus, the utility of attempting to associate cycling actions and effectiveness within this review would be limited. In the future, with large enough samples (of identified initiatives), metaregression techniques may allow such study, but it was not the aim of this review.

There are also a number of limitations to consider. Perhaps most importantly this review was limited to studies published in the English language. We think it is reasonable to assume there is extensive cycling promotion activity in settings such as South America, Continental Europe and China. However, reports of such promotion were not identified in our searches. These areas are therefore under-represented, with a strong bias to the UK, USA and Australia (as reported earlier). It should be noted that UK, USA and Australia are countries with relatively low levels of cycling compared with, for example, certain European countries. It was a pragmatic decision to have the language criterion based on time and resource. While this is consistent with the scoping review process, it is very likely that some initiatives from countries where English is not the first language were missed.

Our review does not provide detailed information on the prevalence or frequency of different cycling promotion initiatives. For example, we identified 16 'bike to work day' reports and one instance of parking restrictions. It is (almost) certain that there are many more of these (and all included actions) taking place globally. Our criteria stated that to be included, actions had to have been described in a study (or publicly available report) and therefore we can give some indication about how often they are written about, but not how often they are being implemented. Despite contacting a broad spectrum of stakeholders, this only contributed $22 \%$ of the included studies, which is unlikely to be a true representation of all initiatives. There is therefore likely to be reporting bias in terms of frequency of action types in our findings.

Future research should explore what actions and combination of actions may be most effective and cost effective for scalable, equitable and sustainable promotion of cycling. This research should consider context and setting. For example, do education actions have differential effects depending on whether good macro-infrastructure such as segregated cycle lanes is already in place? Or does skills training have differential effects by age, gender or current health status? Future research could also consider the interaction between action types and innovative design factors such as co-creation; do recipients prefer and choose different actions to those tasked with implementing these actions? And does addressing this impact success? Further, it is not clear how delivery models that are online, via phone, or face to face for relevant action types for example, education or incentivisation actions changes effects.

In conclusion, we have produced a comprehensive map of actions to inform the design, implementation and evaluation of cycling promotion interventions. This is the first such map and shows a broad range of action types demonstrated as feasible to implement within organisational/group-based initiatives. Our map provides an important tool for communities, employers, practitioners and researchers to use in designing interventions to increase cycling in their own contexts locally, nationally and internationally.

\section{What is already known?}

- It is well established that cycling is beneficial for health and well-being, as well as being a more environmentally sustainable form of travel than motorised vehicles.

- There is good evidence for large-scale environmental restructuring (eg, building cycle networks) as being effective to promote population levels of cycling.

- Less is known about how to promote cycling at individual, group and organisational levels (ie, the actions that may be feasible for workplaces or schools).

\section{What are the key findings?}

This review has identified 93 'Actions' to promote cycling that have been previously implemented and could be used to construct interventions.

\section{Twitter Paul Kelly@narrowboat_paul}

Acknowledgements We would like to thank Marshall Dozier for technical support, and Niamh Hart for research assistance. We would also like to thank Lynn Sloman, Andy Cope and Keith Irving.

Contributors PK, GB and CW led the work. PK, CG, JG, AC, HC, GL and GB conceptualised and designed the review. CW led the searching, study selection and data charting with SB and GB. CW, GL and HC led reporting and categorisation development with CG and JG. PK led the writing of this manuscript with all authors contributing to analysis, interpretation and discussion through multiple meetings and drafts.

Funding This work was funded by British Cycling and HSBC-UK as part of the Cycle Nation Project.

Competing interests None declared.

Patient consent for publication Not required.

Provenance and peer review Not commissioned; externally peer reviewed.

Open access This is an open access article distributed in accordance with the Creative Commons Attribution Non Commercial (CC BY-NC 4.0) license, which permits others to distribute, remix, adapt, build upon this work non-commercially, and license their derivative works on different terms, provided the original work is properly cited, appropriate credit is given, any changes made indicated, and the use is non-commercial. See: http://creativecommons.org/licenses/by-nc/4.0/.

\section{ORCID iD}

Paul Kelly http://orcid.org/0000-0003-1946-9848

\section{REFERENCES}

1 Oja P, Titze S, Bauman A, et al. Health benefits of cycling: a systematic review. Scand J Med Sci Sports 2011;21:496-509. 
2 Laird Y, Kelly P, Brage S, et al. Cycling and walking for individual and population health benefits: a rapid evidence review for health and care system decision-makers. Public Health England, 2018.

3 Kelly P, Kahlmeier S, Götschi T, et al. Systematic review and meta-analysis of reduction in all-cause mortality from walking and cycling and shape of dose response relationship. Int J Behav Nutr Phys Act 2014;11:132.

4 Kahlmeier S, Cavill N, Dinsdale H. Health economic assessment tools (HEAT) for walking and for cycling. Methodology and user quide. Economic assessment of transport infrastructure and policies 2011. Copenhagen: World Health Organization Europe, 2014.

5 Bauman AE, Rissel C, Garrard J. Cycling: getting Australia moving: barriers, facilitators and interventions to get more Australians physically active through cycling: cycling promotion fund. Melbourne, 2008.

6 Sallis JF, Bauman A, Pratt M. Environmental and policy interventions to promote physical activity. Am J Prev Med 1998;15:379-97.

7 Community Preventive Services Task Force. Physical activity: built environment approaches combining transportation system interventions with land use and environmental design. The Community Guide 2016.

8 Mayne SL, Auchincloss AH, Michael YL. Impact of policy and built environment changes on obesity-related outcomes: a systematic review of naturally occurring experiments. Obes Rev 2015;16:362-75.

9 Kärmeniemi M, Lankila T, Ikäheimo T, et al. The built environment as a determinant of physical activity: a systematic review of longitudinal studies and natural experiments. Ann Behav Med 2018;52:239-51.

10 Winters M, Buehler R, Götschi T. Policies to promote active travel: evidence from reviews of the literature. Curr Environ Health Rep 2017;4:278-85.

11 Giles-Corti B, Vernez-Moudon A, Reis R, et al. City planning and population health: a global challenge. Lancet 2016;388:2912-24.

12 Hunter RF, Christian H, Veitch J, et al. The impact of interventions to promote physical activity in urban green space: a systematic review and recommendations for future research. Soc Sci Med 2015;124:246-56.

13 Panter J, Guell C, Humphreys D, et al. Title: can changing the physical environment promote walking and cycling? A systematic review of what works and how. Health Place 2019;58:102161.
14 Stewart G, Anokye NK, Pokhrel S. What interventions increase commuter cycling? A systematic review. BMJ Open 2015;5:e007945.

15 Savan B, Cohlmeyer E, Ledsham T. Integrated strategies to accelerate the adoption of cycling for transportation. Transp Res Part F Traffic Psychol Behav 2017:46:236-49.

16 Porter AK, Kohl HW, Salvo D. Dose-Response association of workplace facilities and policies with commuter bicycling among adults. J Transp Health 2019;14. doi:10.1016/j.jth.2019.100603. [Epub ahead of print: 30 Jul 2019].

17 Fell D, Kivinen E. Investing in Cycling \& Walking: Rapid Evidence Assessment. In: Lyndhurst B, ed. A report for the department for transport, 2016.

18 Rutter $\mathrm{H}$. The dangerous olive of evidence and stop chasing innovation, 2016.

19 Michie S, van Stralen MM, West R. The behaviour change wheel: a new method for characterising and designing behaviour change interventions. Implement Sci 2011;6:42.

20 Arksey H, O'Malley L. Scoping studies: towards a methodological framework. Int I Soc Res Methodol 2005;8:19-32.

21 Michie S, West R, Sheals K, et al. Evaluating the effectiveness of behavior change techniques in health-related behavior: a scoping review of methods used. Trans/ Behav Med 2018;8:212-24.

22 Scheepers CE, Wendel-Vos GCW, den Broeder JM, et al. Shifting from CAR to active transport: a systematic review of the effectiveness of interventions. Transp Res Part $A$ Policy Pract 2014;70:264-80.

23 Bird EL, Baker G, Mutrie N, et al. Behavior change techniques used to promote walking and cycling: a systematic review. Health Psychol 2013;32:829-38.

24 National Institute for Health and Clinical Excellence. Physical activity: walking and cycling (PH41). London, 2012.

25 Fraser SDS, Lock K. Cycling for transport and public health: a systematic review of the effect of the environment on cycling. Eur J Public Health 2011;21:738-43.

26 Yang L, Sahlqvist S, McMinn A, et al. Interventions to promote cycling: systematic review. BMJ 2010;341:c5293.

27 Ogilvie D, Egan M, Hamilton V, et al. Promoting walking and cycling as an alternative to using cars: systematic review. BMJ 2004;329:763. 